\title{
Unravelling the Brand Attractiveness Quotient In Processed Food Industry
}

\author{
Dr Rinalini Pathak Kakati ${ }^{1}$ and Anubhuti Deorah ${ }^{2}$
}

\author{
${ }^{1}$ Professor, Department of Business Administration, Gauhati University, \\ Guwahati-781014, Assam, India \\ ${ }^{2}$ Senior Research Fellow, Department of Business Administration, \\ Gauhati University, Guwahati-781014, Assam, India
}

\begin{abstract}
When there is extreme competition for market share among brands be it a Local, a National or a Global brand, how does a Local brand assess its attractiveness? This paper focuses on assessing the Attractiveness Quotient of a local brand, national and global brands in the Ready to Eat Noodles product category of the Processed Food Industry. Four appeals are used to unravel the Brand Attractiveness, viz. Emotional, Rational, Aspirational and Communicational Appeals. A total of 41 variables are gauged under these appeals, comprising of Familiarity, Distinct Advantage, Bond, Happiness, Visibility, Popularity, Clarity, Cost Justified, Satisfaction, etc. These 41 variables are grouped into nine factors through factor analysis. Responses of more than 150 consumers have been collected. The study not only gauges the various appeals, but also calculates a comprehensive Brand Attractiveness Quotient of the three brands and even presents a pictorial depiction of where the Local Brand stands vis-à-vis the National and Global brands. The findings reveal that the Global brand has the highest mean values across individual appeals followed by the Local Brand and then the National Brands. But in case of overall Brand Attractiveness Global Brand is again the highest, followed by National and then Local Brands.
\end{abstract}

Keywords: Brand Attractiveness, Local Brand, National Brand, Global Brand, Processed Food Industry, Noodles.

\section{Introduction}

The main purpose of any product or service marketer today is to attract its customers towards their Brand and to shine among the sea of Brands available in the market. The market today is well penetrated with not only Local and National Brands but also Global and Multi National Players, pausing a great threat to survival for the small Local Brands, especially in products with less or no differentiation. So now it is vital to understand where one's brand attractiveness lies in comparison to their competitors. This will help Brands to leverage themselves over other brands, and make themselves more attractive by highlighting these areas or features. In cluttered markets, like that of FMCG or Processed Food Industry, building brand effectively can only provide a strategic upper hand. The ability to manage this brand effectively affects a company's growth and profitability in long run and builds consumer loyalty directly than any other strategic decision. Many studies relating to different aspects of branding like positioning, measuring brand equity, growth etc. have enriched the literatures with well-developed models and relationships among factors affecting branding issues. A new area which has been relatively untouched upon by researchers is Brand Attractiveness. Most of the studies focus on physical attractiveness of the brands (Till,Busier, 2000; Underwood, 2003; Klein 2003). In India studies on Brand Attractiveness have been done by Trust Advisory Ltd (TRA, 2013) which states brand attractiveness as a powerful, intangible force, which goes much beyond the physical aesthetics of a brand and which irresistibly draws audiences towards itself.

The Processed Food industry has major big global and national players and they have entered the nook and corner of India. Looking at the immense market growth opportunity, local players are trying to enter this competitive segment. Considering the 
above facts, this study examines the brand attractiveness of a product belonging to Consumer Foods- Ready to eat Noodles category. It evaluates the brand attractiveness quotient of the product (Noodles) for a global brand, national brand and local brand and charts the strategic perspective for the local brand. The study also formulates four hypotheses to find whether significant differences exist in the brand appeals under attractiveness quotient.

In India, packaged food industry has witnessed an exponential growth over past few years. The Indian and Retail industry market size is estimated USD258 billion for 2015; and is expected to reach USD482 billion by 2020 (IBEF, 2017). With increasing investment in FDI, global brands like Danone , Heinz , Twinings Nestle, Nepal's CG Foods (WaiWai noodles), Kraft Foods, etc. are found across major cities and towns in India. . Further looking into demand potential, even local /regional brands have immersed leading to unbeatable competition amongst the brands The fight amongst these brands to increase their brand equity is not only felt in major metros but also in other geographically remote areas of India like the North East Region of India (NER).

Considering the above facts, this study examines the brand attractiveness of a product belonging to Consumer Foods- Ready to eat Noodles category. It evaluates the brand attractiveness quotient of the product (Noodles) for a global brand, national brand and local brand and charts the strategic perspective for the local brand.

\section{Literature Review}

A thorough review of the present body of literature on various branding aspect of Local, National and Global brands focusing on Packaged Goods Industry was conducted. Also comparative analysis of Global, National and Local Brands w.r.t. different branding aspects was done. Some of the notable studies are presented in this section.

Batra, Ramaswamy, Alden, Steenkamp and Ramachander (2000) mentions that Brand Attractiveness of brand perceived as having nonlocal origin, are attitudinally preferred to brands seen as local, for reasons not only of perceived quality but also of social status. This research was conducted for developing countries to see if brands which were not locally produced (particularly Western origin) were favored than products perceived as locally produced and branded. Till and Busier (2000) presented two studies. These studies inspected attractiveness role and proficiency in the"match-up hypothesis". Pérez, Alcañiz and Herrera (2009) examined the impact of Corporate Social Responsibility (CSR) on consumer-company identification ( $\mathrm{C}-\mathrm{C}$ identification). It was seen that CSR generated brand attractiveness by refining brand prestige, coherence and uniqueness thereby increasing buying intensions. Nagashima, Akira (1970), White\&Marmet (1980), Obenniller\&Spangenberg (1989), Papadopoulos, Nicolas, Heslop, Garby\&Avlonitis (1987), Parameswaran, Ravi \& Attila (1987), Reierson, Curtis (1966), Roth, Martin \& Romeo (1992), Shimp\& Snyder (1990), Schooler, Robert \&Sunoo (1969, 1971), Shimp, Terence, Sainiee\& Madden (1993), Stephens, Keith, Fox \& Leonard (1985), Tse, David \&Gorn (1993) have studied various influence of Country of origin (COO) effect on brand attractiveness and product evaluations. Lewis and Stubbs (1999) investigated five firms from UK Food and Beverage sector. They found that national and global brands are trying to capture market by tailoring their brands for regional market, while regional brands are looking to expand.

As research in this domain evolves more depth and sophistication has been seen in the literature. But it is seen that a broader enquiry in the domain of brand attractiveness and consumer behavior is lacking. Gao, Pan, Tse, and Kin, Yim (2006) have done a country specific (China) analysis to study market share performance of foreign and domestic brands, considering three sets of factors, (a) brands' competitive advantages, (b) external market environment and (c) brand existence time period. Benedict, Steenkamp, Batra, Alden (2003) studied perceived brandglobalness (PBG) and its influence on brand attractiveness leading to purchase. Sculling and Kapferer (2004) saw that due to the emphasis on building global brands and restructuring of brand portfolios, many effective local brads were removed. Bronnenberg, Dhar and Dube (2007) specifically studied the consumer packaged food industry across U.S regional markets. They observed that the geographical variation in market shares, perceived quality levels and local players' presence is so high that there is no relevance of a national/ global brand. Ataman, Mela and Heerde (2007) did a study in France markets, an extension study of Bronnenberg, Dhar, and Dube (2007) which was done in US markets which highlighted the impact of geographic variation. Dewsnap and Jobber (2000) specifically studied the Consumer Packaged Goods companies. They found that these companies need to have strong holds in retail trade, relationship an collaborative marketing within the marketing functions are the need of the hour, especially between trade customer-focused sales personnel and brand-focused marketing personnel. Feldman (2011) in his study, reports about making brands, more attractive for retailers and licensees. Spiegler, Hildebrand and Michahelles (2012) argue that 
players have recently introduced the use online social media platform in their businesses; also, there has been spurt of outdoor displays in public places. The focus thus now is how both social media and outdoor advertising can be used to attract potential and existing customers and make strong relationships with the brand in question.

\section{Theoretical Framework}

This study draws partially the theoretical framework of TRA model published in Brand Attractiveness Report (2013). The model mainly works on two aspects Brand Trust and Brand Attractiveness. This study after modifications needed for the specific product category under study, has adapted 41variables from the original 36 Trait Matrix. The Trust Advisory (TRA) Pvt. Ltd, a Comniscient Group company has developed two proprietary matrices: Brand Trust and Brand Attractiveness. It has done an extensive study on measuring Brand Attractiveness in India. Over several years TRA conducted detailed interviews and interactions with psychologists and communication experts to understand the physiology of attraction and concluded on a 36 Trait Matrix, the primary ingredients that constitute all attractions. These ingredients arouse out of four Attractiveness Appeals- Rational, Emotional, Aspirational and Communication, and get woven into the Attractiveness Quotient.Each of the four appeals plays vital role in building brand attractiveness. While some brands may possess one or more of these appeals, having a balanced mix of all four appeals creates a brand that possesses an elusive quality to create a sustained attractiveness. This is a quality that is greatly coveted by all brands as it helps to engage consumers holistically and for a prolonged period of time.

\section{Methodology}

\subsection{Research design}

This study makes use of descriptive research design. The past studies carried out in India and abroad have already identified the various factors that affect brand attractiveness. In this study, attempt has been to identify the differences in brand attractiveness appeals for different brands in the Consumer Food - Ready to eat Noodles category. The 3 brands selected for the study are (i) Yummy, the local brand manufactured by AA Nutritions, (ii)Yippee, the national brand from ITC and (iii) Maggi, the global brand from Nestle. The selections of these brands are based on market share and availability in Greater Guwahati where the study has been conducted. Survey method has been employed for data collection by administering a structured questionnaire. The sample size consisted of 150 customers and the sampling technique used has been judgment sampling. The respondents' had been briefed about the questionnaire format of the study initially before undertaking the survey. Close observation of consumers at the departmental stores and grocery stores had been done to study their purchase behavior of the considered brands.

This study has used the Brand Attractiveness Model published in the report published by TRA (2013) with modifications considering the nature of product under study.

Table 1: Variables studied under each appeal

\begin{tabular}{|l|l|l|l|l|l|l|}
\hline \multicolumn{3}{|l|}{ EMOTIONALAPPEAL } & \multicolumn{2}{l|}{ RATIONALAPPEAL } & ASPIRATIONAL APPEAL & \multicolumn{2}{l|}{ COMMUNCATIONAPPEAL } \\
\hline Familiar & Memory & Expectation & Logical & Satisfaction & Clarity & Interactive \\
\hline Recognition & Happy & Positive Feedback & Track & Pride & Attraction & Meets all Standards \\
\hline Delivers & Alertness & Understandable & Visibility & Connection & Posters & Packaging \\
\hline Association & Confidence & Positive Experience & Popularity & Compliments & Promotions & Stands Out \\
\hline Distinct Advantage & Comforting & Market Standard & Value For Money & Acknowledgement & Trust & \\
\hline Bond & & Presentable & Cost Justified & Enngagement & & \\
\hline & & Systematic & Avallability & Fashionable & & \\
\hline
\end{tabular}

\subsection{Questionnaire}

A format of the questionnaire to test the four appeals is given in Appendix I. The Questionnaire administered has two parts: Screener Questionnaire- This was administered to qualify consumers and Main Questionnaire: The main questionnaire constitute of 41 attributes which have been divided into four sections based on the four appeals to be studied under the objective. The respondents were asked to rate all 41 attributes on a 7 point Likert Scale (1 for strongly disagree to 7 for strongly agree).

\subsection{Scaling techniques}

Consumers' were asked to rate their degree of agreement or disagreement on an assortment of 41 attributes of a brand. For this reason the Likert Scale was used. This measurement is very difficult as it is hidden in consumers subconscious answer is either agree or disagree (i.e. positive or negative), a 7 point scale is decoded where 1 means strongly disagree, 7 means strongly agree and 4 means neither agree nor disagree: neutral response. Respondents were asked to avoid the mid neutral response i.e. acquiescence response bias.Content, criterion and construct validity are followed through.

\subsection{Scale Reliability and Validity for Ready to Eat Noodles Brands}


The reliability and validity of the scale and data collected was conducted. The variables under each appeal were gauged. The scale was tested for internal reliability of scale and sub-scale items. According to various authors (Churchill, 1979; Peter, 1981; and Malhotra, 2004), a multi-item scale should be evaluated for accuracy and applicability, and emphasis should be on developing measures, which have desirable, reliable and valid properties. The measure followed was, reliability with Cronbach's alpha, which is defined as the average of all possible split- half coefficients resulting from different ways of splitting the scale items (Cronbach, 1951) (Table 2).

Table 2: Reliability and Equivalence of Appeals for Ready to Eat Noodles Brands

\begin{tabular}{|l|l|l|l|l|l|l|}
\hline Appeal & $\begin{array}{l}\text { No. of } \\
\text { Items }\end{array}$ & $\begin{array}{l}\text { Cronbanch's } \\
\text { Alpha }\end{array}$ & $\begin{array}{l}\text { Hotellingt } \\
\text { Squared }\end{array}$ & $F$-Value & df & $\begin{array}{l}p \text { - } \\
\text { Value }\end{array}$ \\
\hline Emotional & 11 & 0.94 & 40.3 & 3.929 & $10-349$ & 0.000 \\
\hline Rational & 14 & 0.952 & 60.348 & 4.486 & $13-345$ & 0.000 \\
\hline Aspiration & 7 & 0.916 & 1.593 & 0.253 & $6-354$ & 0.008 \\
\hline Communication & 9 & 0.933 & 22.683 & 2.464 & $8-350$ & 0.010 \\
\hline Overall & 41 & 0.981 & 125.106 & 2.708 & $41-315$ & 0.000 \\
\hline
\end{tabular}

Emotional Appeal, Rational Appeal, Aspirational Appeal and Communication Appeal, all achieved a high Cronbach's alpha coefficient, suggesting high reliability (greater than 0.6 as recommended by Nunally and Bernstein, 1994). 0.9 is seen as a good value for alpha. The overall Cronbach's alpha coefficient for 41 variables was .981 . Hotelling's $t$ squared test confirmed that the mean of different variables under the four appeals vary significantly from each other at 1 per level. This indicates that there is no equivalence between all the 41 variables and they are all different and possess unique characteristics. All $t$-values were significant at 0.5 level of significance.

\subsection{Hypothesis Formulation}

Based on the four appeals, the following hypothesis has been formulated. Testing of these hypotheses will give greater validity to our findings.

$\mathrm{H}_{0}$ : There is no significant differences in Emotional, Rational, Aspirational and Communication Appeals among the global, national and local brand.

$\mathrm{H}_{1}$ : There is significant differences in Emotional, Rational, Aspirational and Communication Appeals among the global, national and local brand

\section{Analysis and Findings}

Out of the sample size of 150 , only 120 completely filled questionnaires have been retrieved, hence the final analysis is based on the sample of 120 consumers.

\subsection{Factor Analysis}

The first step consists of factor analysis in order to reduce the underlying variables affecting an appeal. Factor analysis has been carried out separately for each appeal for all the three brands together as given by the Rotated Component Matrix in Table 3. From the above Rotated Factor Matrices, under Emotional Appeal: two factors, Rational Appeal: three factors, Aspirational Appeal: two factors and Communication Appeal: two factors have been extracted. By grouping the factor loadings with factor scores more than $|0.5|$, the factors have been named as discussed below.

Table 3a: The Rotated Component Factor Matrix for Emotional and Rational Appeals

\begin{tabular}{|c|c|c|c|c|c|c|}
\hline \multicolumn{3}{|l|}{ Emotional Appeal } & \multicolumn{4}{|l|}{ Rational Appeal } \\
\hline & \multicolumn{2}{|c|}{$\begin{array}{l}\text { Component and } \\
\text { Factor Loadings }\end{array}$} & & \multicolumn{3}{|c|}{$\begin{array}{l}\text { Component and } \\
\text { Factor Loadings }\end{array}$} \\
\hline & 1 & 2 & & 1 & 2 & 3 \\
\hline Familiar & 0.813 & & Expectation & 0.81 & & \\
\hline Recognition & 0.705 & & Understandable & 0.71 & & \\
\hline Delivers & 0.816 & & Market Standard & 0.69 & & \\
\hline Association & 0.646 & & Systematic & 0.71 & & \\
\hline Distinct advantage & 0.741 & & Logical & 0.56 & & \\
\hline Bond & 0.75 & & Popularity & & 0.78 & \\
\hline Happy & & 0.58 & Value For Money & & 0.75 & \\
\hline Memory & & 0.84 & Cost Justified & & 0.82 & \\
\hline Alertness & & 0.81 & Availability & & 0.57 & \\
\hline Confidence & & 0.82 & Positive Feedback & & & 0.59 \\
\hline \multirow[t]{4}{*}{ Comforting } & & 0.73 & Positive Experience & & & 0.55 \\
\hline & & & Presentable & & & 0.79 \\
\hline & & & Track & & & 0.57 \\
\hline & & & Visibility & & & 0.82 \\
\hline \multicolumn{7}{|c|}{ Extraction Method: Principal Component Analysis. } \\
\hline \multicolumn{7}{|c|}{ Rotation Method: Varimax with Kaiser Normalization. ${ }^{\text {a }}$} \\
\hline a. Rotation conver & din 3 & maxin & num of 6 iterations. & & & \\
\hline
\end{tabular}

Emotional Appeal: Familiar, Recognition, Delivers, Association, Distinct advantage and Bond fall under first factor. These variables talk about awareness of the brand among consumers hence it has been attributed as Brand Knowledge as used by Keller (1998). Happy, Memory Alertness, Confidence and Comforting variables form the second factor under Emotional appeal. This group of variables reflects the image of the brand so the nomenclature Brand Image as used by Keller (1998) has been given to Factor 2. 
Table 3b: The Rotated Component Factor Matrix for Aspirational and Communication Appeals

\begin{tabular}{|l|l|l|l|l|l|}
\hline \multicolumn{3}{|l|}{ Aspirational Appeal } & \multicolumn{3}{l|}{ Communicational Appeal } \\
\hline & $\begin{array}{l}\text { Component and } \\
\text { Factor Loadings }\end{array}$ & & \multicolumn{3}{|l|}{$\begin{array}{l}\text { Component and } \\
\text { Factor Loadings }\end{array}$} \\
\hline & 1 & 2 & & 1 & 2 \\
\hline Satisfaction & 0.783 & & Clarity & 0.77 & \\
\hline Compliments & 0.758 & & Posters/ Billboards & 0.74 & \\
\hline Acknowledgement & 0.637 & & Interactive & 0.63 & \\
\hline Fashionable & 0.857 & & Meets All Standard & 0.65 & \\
\hline Pride & & 0.78 & Packaging & 0.63 & \\
\hline Connection & & 0.857 & Stands-Out & 0.78 & \\
\hline Engagement & & 0.602 & Attraction & & 0.687 \\
\hline & & & Promotions & & 0.921 \\
\hline & & & Trust & & 0.659 \\
\hline
\end{tabular}

Rational Appeal: Expectation, Understandable, Market Standard, Systematic and Logical form the first factor under rational appeal. These variables reflect rational gratification of consumers. This factor has been named as Brand Satisfaction as defined by Aaker (1996). The second group of variables forming the second factor are Popularity, Value for Money, Cost Justified and Availability. These variables talk about the competence of a brand and so has been nomenclature as Brand Efficiency as defined by Keller and Lehmann (2006). The last variable group under Rational Appeal consists of Positive Feedback, Positive Experience, Presentable, Track and Visibility. This group of variables clearly talks about the performance of the brand over the years hence it can be named as Brand Performance as defined by Keller (2001).

Aspirational Appeal: Satisfaction, Compliments, Acknowledgement and Fashionable form the first factor group under Aspirational appeal. These reflect personal significance of a brand and has been named as Brand Relevance as defined by Keller (2001). The second group of variables is Pride, Connection and Engagement. These variables express how brands' exude individual's own gratification among consumers and accordingly been named Brand Expression as defined by Aaker (1996).

Communication Appeal: The variables under first factor of Communication appeal are Clarity, Posters/ Billboards, Interactive, Meets Standards as communicated, Packaging and Stands-Out. All these variables reflect a brand's promotion tactics with the consumers so the nomenclature Brand's Value Communication Point as defined by Aaker (1996) has been attributed to it. Attraction, Promotions and Trust form the last group under communication appeal. These variables reveal a brand's charm and how its communication is clear so has been named as Brand Reinforcement as defined by Brand Panorama Model (2013).

\subsection{Brand Attractiveness Scores Under Four Appeals}

The statements under each appeal of the main Questionnaire (given in Appendix I) has been evaluated by taking mean scores and standard deviation of their responses. These have been calculated factor wise in order to reduce the data. Finally mean scores and standard deviation of each factor under the four appeals for the three brands have been summarized and given in Table $4 \mathrm{a}$ and Table 4b.

Table 4a: Mean Scores and Deviation of brands under Emotional and Rational Appeals

\begin{tabular}{|c|c|c|c|c|c|c|c|c|c|c|}
\hline \multirow{3}{*}{ Brand } & \multicolumn{4}{|c|}{ Emotional Appeal } & \multicolumn{6}{|c|}{ Rational Appeal } \\
\hline & \multicolumn{2}{|c|}{\begin{tabular}{|l|} 
Brand \\
Knowledge \\
\end{tabular}} & \multicolumn{2}{|c|}{$\begin{array}{l}\text { Brand } \\
\text { Image }\end{array}$} & \multicolumn{2}{|c|}{$\begin{array}{l}\text { Brand } \\
\text { Satisfaction }\end{array}$} & \multicolumn{2}{|c|}{\begin{tabular}{|l|} 
Brand \\
Efficiency
\end{tabular}} & \multicolumn{2}{|c|}{$\begin{array}{l}\text { Brand } \\
\text { Performance }\end{array}$} \\
\hline & Mean & S.D & Mean & S.D & Mean & S.D & Mean & S.D & Mean & S.D \\
\hline Yummy & 4.66 & 1.21 & 4.62 & 1.32 & 4.62 & 1.31 & 4.75 & 1.34 & 4.7 & 1.3 \\
\hline Yippe & 4.5 & 1.15 & 4.42 & 1.03 & 4.44 & 1.16 & 4.74 & $\begin{array}{l}1.11 \\
\end{array}$ & 4.52 & 1. \\
\hline Maggi & 5.41 & 1.1 & 5.34 & 1.06 & 5.24 & 1.21 & \begin{tabular}{|l|}
5.37 \\
\end{tabular} & $\begin{array}{l}1.19 \\
\end{array}$ & 5.57 & 0.96 \\
\hline
\end{tabular}

Table 4b: Mean Scores and Deviation of brands under Aspirational and Communication Appeals

\begin{tabular}{|c|c|c|c|c|c|c|c|c|}
\hline \multirow{3}{*}{ Brand } & \multicolumn{4}{|c|}{ Arpirational Appeal } & \multicolumn{4}{|c|}{ Commmanicurion Afyend } \\
\hline & \multicolumn{2}{|c|}{$\begin{array}{l}\text { Brand } \\
\text { Relenanice }\end{array}$} & \multicolumn{2}{|c|}{$\begin{array}{l}\text { Brand } \\
\text { Eyprezsion }\end{array}$} & \multicolumn{2}{|c|}{$\begin{array}{l}\text { Brand'z Vahe } \\
\text { Commanication Point }\end{array}$} & \multicolumn{2}{|c|}{$\begin{array}{l}\text { Brand } \\
\text { Reinforcemen }\end{array}$} \\
\hline & Mean & S.D & Mean & SD & Mean & SD & Mean & SD \\
\hline Yaray & 469 & 134 & 4.67 & 133 & 48 & 1.27 & 467 & 1.32 \\
\hline Yinpee & 4.63 & 108 & 4.66 & 1.22 & 4.66 & 1.11 & 436 & 1.25 \\
\hline Mage & 534 & 098 & 5.37 & 1.19 & 5.43 & 0.99 & 529 & 1.12 \\
\hline
\end{tabular}

The global brand Maggi scores highest mean score in Brand Knowledge (5.41) and also Brand Image (5.34), followed by the local brand Yummy (4.66, 4.62 respectively) and then the National brand Yippee (4.5, 4.42 respectively) both scoring almost the same under both the factors of emotional appeal. Maggi has the highest mean score in all the three factors under Rational Appeal i.e. Brand Satisfaction (5.24), Brand Efficiency (5.37) and Brand Performance (5.57). All the scores are nearing to 5 . These mean scores confirm that consumers "somewhat agree" to the national brand's performance, efficiency and satisfaction. Yippee has mean score of 4 (approximately) for Brand Performance, Brand Satisfaction and Brand Efficiency, implying that consumers "neither agree nor disagree" to the 3 aspects. The local brand

Yummy lags behind Maggi but little better than Yippee in all the three respects, Brand Performance (4.7), Brand Efficiency (4.75) and Brand Satisfaction (4.62). Consumers "neither agree nor disagree" and are leaning towards "somewhat 
agree" w.r.t. all the three factors. The global brand Maggi scores highest mean score in Brand Relevance (5.34) and in Brand Expression (5.37) followed by the local brand Yummy and Yippee has the least mean score. The local brand Yummy scores little better than the global brand, its Brand Relevance (4.69) is found to be marginally better than Brand Expression (4.67) aspect. Though the difference hardly matters. Consumers lean towards "somewhat agree" and connect positively towards Yummy's Expression and Relevance. The global brand Maggi yet again has the highest mean score in all the factors under Communication Appeal i.e. Brand's Value Communication Point (5.43) and Brand Reinforcement (5.29). These mean scores confirm that consumers "somewhat agree" to the global brand's value communication and reinforcement. The national brand Yippee has mean score of 4.68 and 4.56 respectively for both the factors, implying that the consumers are leaning towards some agreement or are indifferent towards these factors of the brand. The local brand Yummy scores 4.67 for Brand Reinforcement and 4.8 for Brand's Value Communication Point. Furthermore, it is nearing positive feelings in both respect.

The Standard Deviations reflect the consistency in responses of the consumers. The above table reflects that the consumers are most consistent w.r.t. Maggi and Yippee, and least consistent in responses of Yummy. This has implication in calculation of Brand Attractiveness.

\section{3 t Test}

To test whether the three brands differ significantly for all the four Appeals, "One Sample t test" has been performed for each factor belonging to the appeals.

Table 5a: One Sample t test Results for Emotional and Rational Appeals

\begin{tabular}{|c|c|c|c|c|c|c|c|c|c|}
\hline \multirow{3}{*}{ Brand } & \multicolumn{4}{|c|}{ Emotional Appeal } & \multicolumn{5}{|c|}{ Rational Appeal } \\
\hline & \multicolumn{2}{|c|}{$\begin{array}{l}\text { Brand } \\
\text { Knowledge }\end{array}$} & \multicolumn{2}{|c|}{ Brand Image } & \multicolumn{2}{|c|}{$\begin{array}{l}\text { Brand } \\
\text { Satisfaction }\end{array}$} & \multicolumn{2}{|c|}{$\begin{array}{l}\text { Brand } \\
\text { Efficiency }\end{array}$} & \multirow[t]{2}{*}{$\begin{array}{l}\mathrm{Brc} \\
\mathrm{Pe}\end{array}$} \\
\hline & $\mathrm{t}$ & $\begin{array}{l}\text { Sig.(2- } \\
\text { tailed) }\end{array}$ & $\mathrm{t} \mathbf{t}$ & $\begin{array}{l}\text { Sig.(2- } \\
\text { tailed) }\end{array}$ & $\mathrm{t}$ & $\begin{array}{l}\text { Sig.(2- } \\
\text { tailed) }\end{array}$ & $t$ & $\begin{array}{l}\text { Sig.(2- } \\
\text { tailed) }\end{array}$ & \\
\hline Yummy & 42.3 & 0.000 & 38.2 & 0.0 & 38.7 & 0.000 & 38.9 & 0.000 & 39. \\
\hline Yippee & 43.1 & 0.000 & 47 & 0.0 & 42 & 0.000 & 46.8 & 0.000 & 43. \\
\hline Maggi & 53.8 & 0.000 & 55 & 0.0 & 47.3 & 0.000 & 49.4 & 0.000 & 63. \\
\hline
\end{tabular}

Table 5b: One Sample t test Results for Aspiration and Communication Appeals

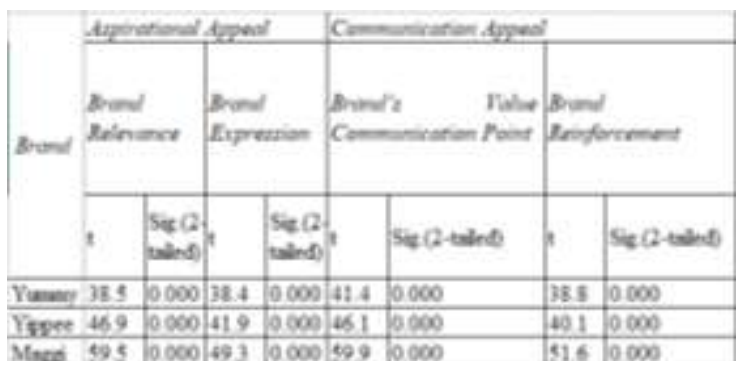

The findings of "One Sample t test" given in Table $5 \mathrm{a}$ and Table $5 \mathrm{~b}$, shows that the calculated $\mathrm{p}$ value $\leq 0.000$ for all the factors. This imply that all the four appeals are significant at 5\% level of significance suggesting that there exists significant differences among the global, national and local brand's regarding the four appeals.

\subsection{Multi-Dimensional Scale for the four Appeals}

To further understand the brand attractiveness, multidimensional scaling also has been performed as given in Table 6, 7 and Figure 1. The Wilks' Lamda value is $0.866(\mathrm{p} \leq 0.000)$, implying that the data is fit for multi-dimensional scaling. By plotting the values given in Table 7 , the Figure 1 has been obtained. The $\mathrm{X}$ axis is represented by Emotional Appeal, Rational, Aspirational and Communication Appeal. The appeals are denoted by orange lines, whereas the Brands are denoted by blue lines. It is clear from the diagram that global brand Maggi has strong association with Emotional, Aspirational and Communication Appeal but it has the potential to go even stronger. On the other hand, the local brand Yummy falls in the third quadrant. The national brand, Yippee seems to also lag behind in any association with the four appeals. Both the local and national brand have a long way to go but Yummy is slightly closer to all the appeals than Yippee.

Table 6: Wilks’ Lambda

\begin{tabular}{|l|l|l|l|l|}
\hline $\begin{array}{l}\text { Test of } \\
\text { Function(s) }\end{array}$ & $\begin{array}{l}\text { Wilks' } \\
\text { Lambda }\end{array}$ & $\begin{array}{l}\text { Chi- } \\
\text { square }\end{array}$ & $d f$ & Sig. \\
\hline 1 through 2 & .866 & 51.264 & 8 & .000 \\
\hline 2 & .994 & 2.036 & 3 & .565 \\
\hline
\end{tabular}


Table 7: Structure Matrix and Group Centroid

\begin{tabular}{|l|l|l|}
\hline DIMENSIONS & X axis values & $\begin{array}{l}Y \text { axis } \\
\text { values }\end{array}$ \\
\hline Emotional Appeal & $.949^{*}$ & 0.085 \\
\hline Rational Appeal & $.944^{*}$ & 0.223 \\
\hline Aspirational Appeal & $.740^{*}$ & 0.63 \\
\hline $\begin{array}{l}\text { Communication } \\
\text { Appeal }\end{array}$ & $.753^{*}$ & 0.263 \\
\hline Yummy & -0.172 & -0.101 \\
\hline Yippee & -0.36 & 0.08 \\
\hline Maggi & 0.532 & 0.021 \\
\hline $\begin{array}{l}\text { Pooled within-groups correlations } \\
\text { discriminating variables and standardized canonical } \\
\text { discriminant functions. }\end{array}$ \\
\hline $\begin{array}{l}\text { Variables ordered by absolute size of correlation } \\
\text { within function. }\end{array}$ \\
\hline $\begin{array}{l}\text { *Largest absolute correlation between each variable } \\
\text { and any discriminant function }\end{array}$ \\
\hline
\end{tabular}

Figure 1: Multi-Dimensional Scaling for Ready to Eat Noodles Brands

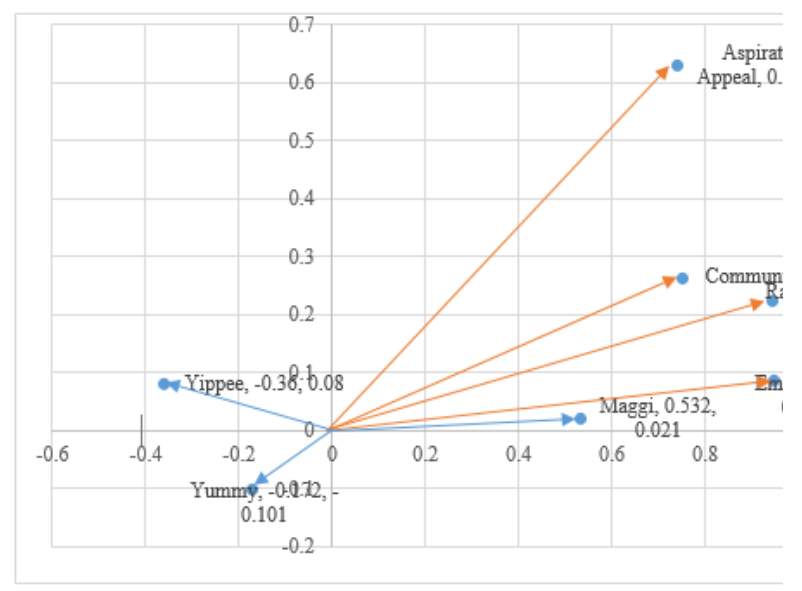

\subsection{Brand Attractiveness Quotient of the three Brands}

This study draws partially the method of calculation of Brand Attractiveness Quotient used in TRA Brand Trust Report (2013). Some adaptations have been done based on the questions included in the questionnaire. The Attractiveness Quotient has been calculated based on the following parameters:

- Brand Recall: The number of times a brand's name occurs

- Position score: Calculated on the basis of respondent's recall preference.
- Suitability score given to each brand with relation to the specific attribute, measured as the Standard Deviation of the brand's suitability to the overall suitability Standard Deviation

- Brand Average suitability, measured as the mean of the brand's suitability for each attribute

For our study we have used the same quotient (described mathematically in an equation) stated above with some modifications, according to the suitability of the study (TRA Brand Trust Report, 2013). The equation used comprises of all the four parts Brand Recall, Position Score, Standard deviation suitability score and the Brand Average suitability score. This can be represented mathematically as Eq. (1):

$$
\frac{S D_{0}}{S D_{i}} \times P_{3 i} \times O_{3 i} \times \bar{X}_{3 i}
$$

Where,

- $S D_{0}$ : Represents overall 4 brand appeals' standard deviation value (cumulative)

- $S D_{i}$ : Represents all $\mathrm{i}^{\text {th }}$ brand appeals' standard deviation

- $O_{3 i}$ : Represents $i^{\text {th }}$ brand recall frequency to total respondents

- $P_{3 i}$ : Represents $i^{\text {th }}$ brand relative position score

- $\bar{X}_{3 i}$ : Represents $i^{\text {th }}$ brand appeals' average value

The following table represents the same for the three brands:

Table 8: Attractiveness Quotient of the three Brands

\begin{tabular}{|l|l|l|l|l|l|l|l|l|l|}
\hline Brand & $S D_{4}$ & $S D_{i}$ & $\frac{S D_{6}}{S D_{i}}$ & $\begin{array}{l}\text { Position } \\
\text { Recall } \\
\text { Sosition }\end{array}$ & $\begin{array}{l}\text { Brand } \\
\text { Recall } \\
\text { Frequency }\end{array}$ & $\begin{array}{l}\text { Brand } \\
\text { Recall } \\
\text { Score } \\
\bar{O}_{\mathrm{Hi}}\end{array}$ & $\begin{array}{l}\text { Brand } \\
\text { Average } \\
\bar{X}_{3 i}\end{array}$ & $\begin{array}{l}\text { Brand } \\
\text { Attractiveness } \\
\text { Quotient }\end{array}$ \\
\hline Yummy & 1.415 & 1.3029 & 1.086 & 3 & 0.5 & 63 & 0.525 & 4.685 & 1.336 \\
\hline Yippee & 1.415 & 1.1392 & 1.242 & 2 & 0.667 & 100 & 0.833 & 4.578 & 3.159 \\
\hline Maggi & 1.415 & 1.085 & 1.304 & 1 & 0.833 & 113 & 0.942 & 5.368 & 5.493 \\
\hline
\end{tabular}

$S D_{0}$ is 1.415 which represents the grand average of overall standard deviations of four appeals for all the three brands taken together. The $i^{\text {th }}$ brand appeals' standard deviation $\left(S D_{i}\right)$ is for Yummy, Yippee and Maggi are 1.3029, 1.1392 and 1.085 this means that Maggi has the least deviations in responses among the consumers followed by Yippee and then Yummy. This is the reason why $\frac{S D_{0}}{S D_{i}}$ reflect the order of Maggi, followed by Yippee and then Yummy, even though Yummy has higher 
mean values than Yippee. The overall four brand appeals' standard deviation value (which is the same for all the three brands) divided by individual brand average of four appeals' standard deviation reflect the highest score of 1.304 for Maggi, seconded by Yippee 1.242 and then by Yummy 1.086. The brand recall position and frequency reflect the same rankings. We have given score to position by dividing the recall position by summation of all position score i.e. 6, and then by subtracting that value by 1 . Yummy's score is 0.5 , Yippee's is 0.667 and Maggi's is 0.833 . The Brand recall score is nothing but Brand Recall number divided by total number of respondents (120 for ready to eat noodles category). Yummy's score is 0.525 , Yippee's is 0.833 and Maggi's is 0.942 . Brand Average mean reflects the average of the mean scores of all the respondents for each brand. Thus by multiplying these four components (as given in Eq.1) i.e. Standard deviation score, Position score, Brand Recall score and the Brand Average score we derive the Brand Attractiveness Quotient. What we see in the noodles category is concisely what has reflected in all our above analysis, i.e. Maggi has the highest attractiveness quotient of 5.493, followed by Yippee 3.159 and then by Yummy 1.336. This reflects the gap in attractiveness among the brands and clearly Yummy lags behind in attractiveness and both Maggi and Yippee exceed in attractiveness by a good margin.

\section{Conclusion}

This section discusses the various marketing implications of the analysis done in the previous sections. 41 variables were measured on the scale, which was tested for reliability and validity. The overall Cronbach's alpha coefficient was .981. The emotional appeal primarily reflects the brands' connect with its customers like whether the brand triggers some memory or brand is familiar and recognized. Maggi scores the most w.r.t. Emotional Appeal followed by Yippee and Yummy. This is so because Maggi is the oldest player in the market and it occupies a special place in the consumption basket of every household not only in Assam but also in India. Under this study, rational appeal majorly reflects on the factual side of a consumer that means the cost factor, distribution and the share of wallet, etc. The mean values reflect that Maggi is a step ahead of Yummy and Yippee. Also in case of Aspirational appeal, which reflect the motivating factors for a consumer to pick up a product, also reflect the same trend. The communication appeal reflects all forms of communication to the consumers. Again Maggi has the highest mean value but Yummy and Yippee follow closely. In case of both Aspiration and Communication appeal, Maggi is the frontrunner again compared to Yummy and Yippee. This implies that the consumers strongly associate to the brand.

MDS implication: The global brand Maggi has strong association with Emotional, Aspirational and Communication Appeal but it has the potential to go even stronger. On the other hand, the local brand Yummy falls in the third quadrant. Both the local and national brand have a long way to go but Yummy is slightly closer to all the appeals than Yippee.

Maggi has the highest attractiveness quotient of 5.493, followed by Yippee 3.159 and then by Yummy 1.336. This reflects the gap in attractiveness among the brands and clearly Yummy lags behind in attractiveness and both Maggi and Yippee exceed in attractiveness by a good margin. Though Yummy has better mean values than Yippee, it still lags behind because of individual Standard Deviation $\left(S D_{i}\right)$. Yummy is the most inconsistent in consumer responses, resulting in high deviations. All the above analysis reflects that the Local Brand Yummy is the least attractive compared to the National Brand Yippee and Global Brand Maggi. This is of grave concern as the success of a local brand is of great importance to the state of origin. The above brand attractiveness analysis also points out that positioning a local brand is very difficult as there is no special appeal attached to it. 


\section{Appendix I-}

\section{Screener Questionnaire}

Name:

Email/ Phone no.

Gender:

M

F

Age (in years):

13-19

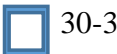

$\square 35-40$

$\square 0$

Marital Status:

Married

Single

Divorced

Family Size:

$<4$

4-6

6-8

$>8$

Do you purchase the day to day grocery items for your household?

YES

NO

Are you also the decision maker of the same?

YES

NO

Name 9 Noodles brands which you can recall now: ( 3 multinational brands, 3 national brands and 3 local/ regional brands)

\begin{tabular}{|l|l|l|l|}
\hline & Brand 1 & Brand 2 & Brand 3 \\
\hline Multinational & & & \\
\hline National & & \\
\hline Local/ Regional & & \\
\hline
\end{tabular}

Main Questionnaire

Please indicate how much you agree or disagree with each of the following statements for each of the 3 brands separately: Key to answer:

\begin{tabular}{|l|l|l|l|l|l|l|l|}
\hline SCALE & 1 & 2 & 3 & 4 & 5 & 6 & 7 \\
\hline MEANING & $\begin{array}{l}\text { Strongly } \\
\text { Disagree }\end{array}$ & Disagree & $\begin{array}{l}\text { Somewhat } \\
\text { Disagree }\end{array}$ & $\begin{array}{l}\text { Neither } \\
\text { Agree } \\
\text { nor } \\
\text { Disagree }\end{array}$ & $\begin{array}{l}\text { Somewhat } \\
\text { Agree }\end{array}$ & Agree & $\begin{array}{l}\text { Strongly } \\
\text { Agree }\end{array}$ \\
\hline
\end{tabular}




\begin{tabular}{|c|c|c|c|c|c|c|c|c|c|c|c|c|c|c|c|c|c|c|c|c|c|c|}
\hline ATTRIBUTES & & UN & DV & & & & & & $\mathbf{I}$ & & & & & & & & & & & & & \\
\hline 1. It is a familiar brand & 1 & 2 & 3 & 4 & 5 & 6 & 7 & 1 & 2 & 3 & 4 & 5 & 6 & & 7 & 1 & 2 & 3 & 4 & 5 & 6 & 7 \\
\hline $\begin{array}{l}\text { 2. You can recognize the products that the } \\
\text { brand offers }\end{array}$ & 1 & 2 & 3 & 4 & 5 & 6 & 7 & 1 & 2 & 3 & 4 & 5 & 6 & & 7 & 1 & 2 & 3 & 4 & 5 & 6 & 7 \\
\hline $\begin{array}{l}\text { 3. The brand delivers on its potential (in } \\
\text { comparis on with others) }\end{array}$ & 1 & 2 & 3 & 4 & 5 & 6 & 7 & 1 & 2 & 3 & 4 & 5 & 6 & & 7 & 1 & 2 & 3 & 4 & 5 & 6 & 7 \\
\hline $\begin{array}{l}\text { 4. Feeling of association (the sense of self) } \\
\text { with the brand }\end{array}$ & 1 & 2 & 3 & 4 & 5 & 6 & 7 & 1 & 2 & 3 & 4 & 5 & 6 & & 7 & 1 & 2 & 3 & 4 & 5 & 6 & 7 \\
\hline $\begin{array}{l}\text { 5. The brand provides a distinct advantage } \\
\text { on usage, compared with others. }\end{array}$ & 1 & 2 & 3 & 4 & 5 & 6 & 7 & 1 & 2 & 3 & 4 & 5 & 6 & & 7 & 1 & 2 & 3 & 4 & 5 & 6 & 7 \\
\hline $\begin{array}{l}\text { 6. There is a connection/ bond established } \\
\text { with the brand. }\end{array}$ & 1 & 2 & 3 & 4 & 5 & 6 & 7 & 1 & 2 & 3 & 4 & 5 & 6 & & 7 & 1 & 2 & 3 & 4 & 5 & 6 & 7 \\
\hline $\begin{array}{l}\text { 7. You are happy with the brand at all levels } \\
\text { put together (i.e., cost, distinctiveness, and } \\
\text { taste) }\end{array}$ & 1 & 2 & 3 & 4 & 5 & 6 & 7 & 1 & 2 & 3 & 4 & 5 & 6 & & 7 & 1 & 2 & 3 & 4 & 5 & 6 & 7 \\
\hline 8. Brand triggers memory and thoughts & 1 & 2 & 3 & 4 & 5 & 6 & 7 & 1 & 2 & 3 & 4 & 5 & 6 & & 7 & 1 & 2 & 3 & 4 & 5 & 6 & 7 \\
\hline 9. Brand exudes alertness & 1 & 2 & 3 & 4 & 5 & 6 & 7 & 1 & 2 & 3 & 4 & 5 & 6 & & 7 & 1 & 2 & 3 & 4 & 5 & 6 & 7 \\
\hline 10. Brand reflec & 1 & 2 & 3 & 4 & 5 & 6 & 7 & 1 & 2 & 3 & 4 & 5 & 6 & & 7 & 1 & 2 & 3 & 4 & 5 & 6 & 7 \\
\hline $\begin{array}{l}\text { 11. The brand's appearance is comforting } \\
\text { (brand presence is soothing) }\end{array}$ & 1 & 2 & 3 & 4 & 5 & 6 & 7 & 1 & 2 & 3 & 4 & 5 & 6 & & 7 & 1 & 2 & 3 & 4 & 5 & 6 & 7 \\
\hline $\begin{array}{l}\text { 12. The brand qualities match your } \\
\text { expectation from the product }\end{array}$ & 1 & 2 & 3 & 4 & 5 & 6 & 7 & 1 & 2 & 3 & 4 & 5 & 6 & & 7 & 1 & 2 & 3 & 4 & 5 & 6 & 7 \\
\hline $\begin{array}{l}\text { 13. Heard pos itive feedback of the brand from } \\
\text { peers/ users of the brand }\end{array}$ & 1 & 2 & 3 & 4 & 5 & 6 & 7 & 1 & 2 & 3 & 4 & 5 & 6 & & 7 & 1 & 2 & 3 & 4 & 5 & 6 & 7 \\
\hline 14. The brand is easy to understand & 1 & 2 & 3 & 4 & 5 & 6 & 7 & 1 & 2 & 3 & 4 & 5 & 6 & & 7 & 1 & 2 & 3 & 4 & 5 & 6 & 7 \\
\hline $\begin{array}{l}\text { 15. Experience is always positive with the } \\
\text { brand whenever it comes in contact (used, } \\
\text { seen or spoken about }\end{array}$ & 1 & 2 & 3 & 4 & 5 & 6 & 7 & 1 & 2 & 3 & 4 & 5 & 6 & & 7 & 1 & 2 & 3 & 4 & 5 & 6 & 7 \\
\hline eres to Market standard & 1 & 2 & 3 & 4 & 5 & 6 & 7 & 1 & 2 & 3 & 4 & 5 & 6 & & 7 & 1 & 2 & 3 & 4 & 5 & 6 & 7 \\
\hline always well presented & 1 & 2 & 3 & 4 & 5 & 6 & 7 & 1 & 2 & 3 & 4 & 5 & 6 & & 7 & 1 & 2 & 3 & 4 & 5 & 6 & 7 \\
\hline $\begin{array}{l}\text { 18. The brand follows a systematic process in } \\
\text { its action }\end{array}$ & 1 & 2 & 3 & 4 & 5 & 6 & 7 & 1 & 2 & 3 & 4 & 5 & 6 & & 7 & 1 & 2 & 3 & 4 & 5 & 6 & 7 \\
\hline $\begin{array}{l}\text { 19. The actions taken by the brand is } \\
\text { understandable }\end{array}$ & 1 & 2 & 3 & 4 & 5 & 6 & 7 & 1 & 2 & 3 & 4 & 5 & 6 & & 7 & 1 & 2 & 3 & 4 & 5 & 6 & 7 \\
\hline $\begin{array}{l}\text { 20. The brand demonstrates a good track } \\
\text { record }\end{array}$ & 1 & 2 & 3 & 4 & 5 & 6 & 7 & 1 & 2 & 3 & 4 & 5 & 6 & & 7 & 1 & 2 & 3 & 4 & 5 & 6 & 7 \\
\hline $\begin{array}{l}\text { 21. The brand's visibility has increased over } \\
\text { the years }\end{array}$ & 1 & 2 & 3 & 4 & 5 & 6 & 7 & 1 & 2 & 3 & 4 & 5 & 6 & & 7 & 1 & 2 & 3 & 4 & 5 & 6 & 7 \\
\hline $\begin{array}{l}\text { 22. The brand has become popular over the } \\
\text { years }\end{array}$ & 1 & 2 & 3 & 4 & 5 & 6 & 7 & 1 & 2 & 3 & 4 & 5 & 6 & & 7 & 1 & 2 & 3 & 4 & 5 & 6 & 7 \\
\hline $\begin{array}{l}\text { 23. The brand meets 'Value for money' } \\
\text { proposition/ right price bracket }\end{array}$ & 1 & 2 & 3 & 4 & 5 & 6 & 7 & 1 & 2 & 3 & 4 & 5 & 6 & & 7 & 1 & 2 & 3 & 4 & 5 & 6 & 7 \\
\hline $\begin{array}{l}\text { 24. The cost of product is justified with } \\
\text { respect to the value provided (Is it worth the } \\
\text { money?) }\end{array}$ & 1 & 2 & 3 & 4 & 5 & 6 & 7 & 1 & 2 & 3 & 4 & 5 & 6 & & 7 & 1 & 2 & 3 & 4 & 5 & 6 & 7 \\
\hline 25. The brand is easily & 1 & 2 & 3 & 4 & 5 & 6 & 7 & 1 & 2 & 3 & 14 & 5 & 6 & & 7 & 1 & 2 & 3 & 4 & $?$ & 6 & I \\
\hline
\end{tabular}




\begin{tabular}{|c|c|c|c|c|c|c|c|c|c|c|c|c|c|c|c|c|c|c|c|c|}
\hline 26. Owning the brand, makes you satisfied & 112 & 2 & 3 & 4 & 56 & 6 & 7 & 1 & 2 & 3 & 4 & 56 & $6 \quad 7$ & 71 & 2 & 3 & 4 & 5 & 6 & \\
\hline 7. Ow & 2 & 2 & 3 & 4 & $5 \mid 6$ & 6 & 7 & 1 & 2 & 3 & 4 & 56 & $6 \mathbf{7}$ & 71 & 2 & 3 & 4 & 5 & 6 & \\
\hline 28. $\mathrm{F}$ & 11 & 2 & 3 & 4 & 56 & 6 & 7 & 1 & 2 & 3 & 4 & $5 \mid 6$ & 67 & \begin{tabular}{l|l|}
7 & 1
\end{tabular} & 2 & 3 & 4 & 5 & 6 & \\
\hline ts & 1 & 2 & 3 & 4 & 5 & 6 & 7 & 1 & 2 & 3 & 4 & 56 & 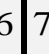 & \begin{tabular}{l|l|l}
7 & 1
\end{tabular} & 2 & 3 & 4 & 5 & 6 & 7 \\
\hline peers, acknowledgement was received & 1 & 2 & 3 & 4 & 5 & 6 & 7 & 1 & 2 & 3 & 4 & $5 \mid 6$ & $6 / 7$ & $7|1|$ & 2 & 3 & 4 & 5 & 6 & 7 \\
\hline $\begin{array}{l}\text { 31. The brand gives priority to continuous } \\
\text { engagement with its audience. }\end{array}$ & 1 & 2 & 3 & 4 & 56 & 6 & 7 & 1 & 2 & 3 & 4 & $5 \mid 6$ & $6 / 7$ & $7 \mid 1$ & 2 & 3 & 4 & 5 & 6 & 7 \\
\hline $\begin{array}{l}\text { 32. The brand appeals to your fashionable } \\
\text { side }\end{array}$ & 1 & 2 & 3 & 4 & 56 & 6 & 7 & 1 & 2 & 3 & 4 & $5 \mid 6$ & $6 / 7$ & $7 \mid 1$ & 2 & 3 & 4 & 5 & 6 & 7 \\
\hline 33. & 1 & 2 & 3 & 4 & 5 & 6 & 7 & 1 & 2 & 3 & 4 & 56 & 67 & \begin{tabular}{ll|}
7 & 1
\end{tabular} & 2 & 3 & 4 & 5 & 6 & 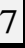 \\
\hline er & 1 & 2 & 3 & 4 & 5 & 6 & 7 & 1 & 2 & 3 & 4 & 5 & $6 / 7$ & $7 \mid 1$ & 2 & 3 & 4 & 5 & 6 & 7 \\
\hline $\begin{array}{l}\text { 35. The po } \\
\text { attractive }\end{array}$ & 1 & 2 & 3 & 4 & 5 & 6 & 7 & 1 & 2 & 3 & 4 & 56 & $6 / 7$ & $7 \mid$ & 2 & 3 & 4 & 5 & 6 & 7 \\
\hline $\begin{array}{l}\text { 36. The pro } \\
\text { us eful }\end{array}$ & 1 & 2 & 3 & 4 & 5 & 6 & 7 & 1 & 2 & 3 & 4 & 56 & 67 & $7|1|$ & 2 & 3 & 4 & 5 & 6 & 7 \\
\hline $\begin{array}{l}\text { 37. The } \\
\text { with sta }\end{array}$ & 1 & 2 & 3 & 4 & 5 & 6 & 7 & 1 & 2 & 3 & 4 & 5 & $6 / 7$ & $7 \mid$ & 2 & 3 & 4 & 5 & 6 & 7 \\
\hline d action arises from interactive & 1 & 2 & 3 & 4 & 5 & 6 & 7 & 1 & 2 & 3 & 4 & 5 & 67 & $7 \mid$ & 2 & 3 & 4 & 5 & 6 & 7 \\
\hline $\begin{array}{l}\text { 39. The brand meets all the standards (taste, } \\
\text { fragrance, appearance, etc.) as promised in all } \\
\text { its communication (TV, Radio, Print, etc.) }\end{array}$ & 1 & 2 & 3 & 4 & 5 & 6 & 7 & 1 & 2 & 3 & 4 & 5 & $6 / 7$ & $7 \mid$ & 2 & 3 & 4 & 5 & 6 & 7 \\
\hline 40. The brand & 12 & 2 & 3 & 4 & 5 & 6 & 7 & 1 & 2 & 3 & 4 & 56 & 67 & $7 \mid 1$ & 2 & 3 & 4 & 5 & 6 & 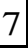 \\
\hline competitors & 12 & 2 & & 4 & & & & 1 & 2 & 3 & & & 6 & & 2 & & 4 & & 6 & \\
\hline
\end{tabular}




\section{Acknowledgement}

This research work wouldn't have been possible without the contributions of the HOD, Faculty and Staff of the MBA Dept., Gauhati University. We would like to thank all the consumer respondents for taking out the time to fill in the survey. We would also thank our families for their support.

\section{References}

[1] AA Nutritions. http://www.yummyfoods.co.in/, Accessed Feb 10, 2016.

[2] Aaker D A, Building Strong Brands. The Free Press, (1996).

[3] Ataman M B, Mela C F and Heerde H J, Consumer Packaged Goods in France: National Brands, Regional Chains, and Local Branding. Journal of Marketing Research, Vol 44(Issue 1): 14-20, (2007).

[4] Batra R, Ramaswamy V, Alden D L , Steenkamp J B E M and Ramachander S, Effects of Brand Local and Nonlocal Origin on Consumer Attitudes in Developing Countries. Journal of Consumer Psychology, 9(2), 83-95, (2000).

[5] Benedict J, Steenkamp, J B E M, Batra R and Alden D L, How Perceived Brand Globalness (PBG) Creates Brand Value.

[13] Definitional Principles in Consumer Identification with a Socially Responsible Company. Journal of Business Ethics, Vol. 89, No. 4, pp. 547-564, (2009).

[14] Dewsnap B and Jobber D, The SalesMarketing Interface in Consumer PackagedGoods Companies: A Conceptual Framework. The Journal of Personal Selling and Sales Management, 20(2), 109-119, (2000)

[15] Douglas S P, Craig C S and Nijssen E J, Integrating Branding Strategy across Markets: Building International Brand Architecture. Journal of International Marketing, Vol. 9, No. 2 (2001), pp. 97-114, (2001).

[16] Feldman A, How to Make a Brand More Attractive to Licensees and Retailers. LMCA, (2016).

[17] Gao G Y, Pan Y, Tse D K and Yim C K, Market Share Performance of Foreign and Domestic Brands in China. Journal of International Marketing, 14(2), 32-51, (2006).

[18] India Brand Equity Foundation (IBEF), Food Processing. www.ibef.org, Accessed August 2017, (2017).
Journal of International Business Studies, Vol. 34, No. 1, pp. 53-65, (2003).

[6] Brand Panaroma (LLC), The Impact of Consumer-Brand Relationships on Market Value. Brand Panaroma from Insight to Outlook, (2013).

[7] Bronnenberg B J, Dhar S K and Dube J P, Consumer Packaged Goods (CPG) in the United States: National Brands, Local Branding. Journal of Marketing Research, Vol. 44, No. 1, pp. 4-13, (2007).

[8] Bronnenberg B J, Dhar S K and Dube J P, National Brands, Local Branding: Conclusions and Future Research Opportunities. Journal of Marketing Research, Vol. 44, No. 1, pp. 26-32, (2007).

[9] Churchill G A, A Paradigm for Developing Better Measures of Marketing Constructs. Journal of Marketing Research, Vol XVI (February), 64-73, (1979).

[10]Collinson S and Rugman A M, The Regional Nature of Japanese Multinational Business. Journal of International Business Studies, Vol. 39, No. 2, pp. 215-230, (2008).

[11] Cronbach L J, Coefficient alpha and the internal structure of tests. Psychometrika, 16, 297- 334, (1951).

[12] Currás-Pérez R, Bigné-Alcañiz E and Alvarado-Herrera A, The Role of Self-

[19] Indian Tobacco Company (ITC). http://www.itcportal.com/businesses/fmcg/fo ods/yippee.aspx, Accessed Jan 23, 2016.

[20] Indian Tobacco Company (ITC). http://www.sunfeastyippee.com/, Accessed Jan 23, 2016.

[21]IS Advisors, FMCG Sector in India: Strategic Review (Budget 2013-14), (2013).

[22] Schuiling I and Kapferer J N, Real Differences between Local and International Brands: Strategic Implications for International Marketers. Journal of International Marketing, Vol. 12, No. 4, 97112, (2004).

[23] Keller K L, Building customer-based brand equity: A blueprint for creating strong brands. Journal of Marketing Management, 10, 15-19, (2001).

[24] Keller K L and Aaker D A, Corporate-level marketing: The impact of credibility on a company's brand extensions. Corporate Reputation Review, 1, 356-378, (1998).

[25] Keller K L, Brand Synthesis: The Multidimensionality of Brand Knowledge. The Journal of Consumer Research, Vol. 29, No. 4, pp. 595-600, (2003). 
[26] Keller K L, Strategic Brand Management: Building, Measuring, and Managing Brand Equity. $4^{\text {th }}$ Edition, Pearson, (2006).

[27] Keller K L and Lehmann D R, Brands and Branding: Research Findings and Future Priorities. Marketing Science, 25 (6), 740 59, (2006).

[28] Keller K L, Parameswaran M G and Jacob I, Strategic Brand Management. $3^{\text {rd }}$ Edition, Pearson, (2011).

[29] Kerner N and Pressman G, Chasing Cool Theory: Standing Out in Today's Cluttered Marketplace. Atria Books, (2007).

[30] Kothari C R, Research Methodology: Methods \& Technique. $2^{\text {nd }}$ Edition, New Age International (P) Ltd, (2004)

[31] Kothari C R, Quantitative Techniques. $3^{\text {rd }}$ edition, Vikas Publishing House, (2009).

[32] Lewis C and Stubbs S, National Expansion of British regional brands: parallels with internationalization. Journal of Product \& Brand Management, Vol. 8, Issue: 5, 369386, (1999).

[33] Malhotra K N. Measurement and Scaling: Non - Comparative Scaling Techniques. In: Marketing Research: An Applied Orientation, Fourth Edition, Pearson Education, 254-277, (2005).

[34] Malhotra N K and Dash S, Marketing Research: An Applied Orientation. $6^{\text {th }}$ Edition, Pearson India, (2010).

[35] Ministry of food processing India (MOFPI), Annual Reports. Government of India, (2004- 2014).

[36] Nagashima A, A Comparison of Japanese and U.S. Attitudes toward Foreign Products. Journal of Marketing, Vol. 34, 68-74, (1970).

[37] Nestle. https://www.nestle.in/brands/maggi2minutenoodles, Accessed Jan. 20, 2016.

[38] Niffenberger P, White J and Marmet G, How British Retail Managers View French and American Products. European Journal of Marketing, 14(8), 493-498, (1980).

[39] Nunnally J C and Bernstein I H, Psychometric theory. $3^{\text {rd }}$ edition, New York: McGraw Hill, (1994).

[40] Obenniller C and Spangenberg E. Exploring the effects of country of origin labels: An information processing framework. In: Thomas K. Srull, editor, Advances in consumer research, Provo, Utah: Association for Consumer Research, Vol. 16, 454-59, (1989).

[41] Papadopoulos N G, Heslop L A, Garby F and Avlonitis G, Does 'country of origin' matter? Some findings from a cross-cultural study of consumer views about foreign products.
Report No. 87-104. Cambridge, Mass.: Marketing Science Institute, (1987).

[42] Parameswaran R and Attila Y, A crossnational comparison of consumer research measures. Journal of International Business Studies, 18(1), 35-49, (1987).

[43]Pérez R C, Alcañiz E B and Herrera A A, The Role of Self-Definitional Principles in Consumer Identification with a Socially Responsible Company. Journal of Business Ethics, 89(4), 547-564, (2009).

[44] Peter J P, Construct Validity: A Review of Basic Issues and Marketing Practices. Journal of Marketing Research, Vol XVIII (May), 133-145, (1981).

[45] PwC report, Innovation in FMCG. PwC, (2013).

[46] Reierson C, Are foreign products seen as national stereotypes? Journal of Retailing, 42 (Fall), 33-40, (1966).

[47]Riezebos R and Grinten J V D, Positioning the Brand: An inside out approach. $3^{\text {rd }}$ Edition, Routledge, (2012).

[48] Roth M S and Jean B R, Matching product category and country image perceptions: A framework for managing country-of-origin effects. Journal of International Business Studies, 23(3), 477-97, (1992).

[49]Rugman A M and Verbeke A, A Perspective on Regional and Global Strategies of Multinational Enterprises. Journal of International Business Studies, Vol. 35, No. 1 (Jan., 2004), 3-18, (2004).

[50] Saeed S, Carape L, Shimp T and Snyder D (1990). Consumers' cognitive structures for countries and their products. Enhancing knowledge development in marketing. In William Bearden et al., editors, Enhancing knowledge development in marketing, Vol. 1 (Summer), 43, (1990).

[51]Schooler, Robert D and Sunoo D H, Consumer Perceptions of International Products: Regional vs. National Labelling. Social Science Quarterly, 49(4), 886-890, (1969, 1971).

[52] Schuiling I and Kapferer J N, Real Differences between Local and International Brands: Strategic Implications for International Marketers. Journal of International Marketing, Vol. 12, No. 4, 97112, (2004).

[53] Sengupta S, Brand Positioning: Strategies for Competitive Advantage. $2^{\text {nd }}$ Edition, Tata McGraw-Hill, (2005).

[54] Shimp, Terence A, Samiee S. and Madden T, Countries and their products: A cognitive structure perspective. Journal of the 
Academy of Marketing Science, 21 (Fall), 323-30, (1993).

[55] Spiegler E D, Hildebrand C and Michahelles F. Increasing Brand Attractiveness and Sales through Social Media Comments on Public Displays - Evidence from a Field Experiment in the Retail Industry. Proceedings of the $10^{\text {th }}$ international conference on Pervasive Computing, ResearchGate, (2012).

[56] Stephens, Keith T, Fox H W and Leonard M J. A comparison of preferences concerning the purchase of domestic vs. imports. In Naresh K. Malhotra, editor, Developments in marketing science, Coral Gables, Fl.: Academy of Marketing Science, 8, 100-104, (1985).

[57] The Trust Advisory Pvt. Ltd. (2013). The Brand Trust Report, Comniscient Group, (2013).

[58] The World Food India 2017. MOFPI Annual Report,

http://www.mofpi.nic.in, www.worldfoodindia.nic.in, Accessed July, 2017, (2016-2017)

[59]Till B D and Busier M, The Match-up Hypothesis: Physical Attractiveness, Expertise, and the Role of Fit on Brand Attitude, Purchase Intent and Brand Beliefs. Journal of Advertising, Vol. 29 (No. 3), 1-13, (2000).

[60] Tse D K and Gorn G J, An Experiment on the Salience of Country-of-Origin in the Era of Global Brands. Journal of International Marketing, 1(1), 57-76, (1993).

[61] Underwood R L and Klein N M, Packaging as Brand Communication: Effects of Product Pictures on Consumer Responses to the Package and Brand. Journal of Marketing Theory and Practice, Vol. 10, No. 4, pp. 58$68,(2002)$.

[62] Underwood R L, The Communicative Power of Product Packaging: Creating Brand Identity via Lived and Mediated Experience. Journal of Marketing Theory and Practice, Vol.

1 ,

(2003). 